\title{
Psychological problems of learning from home during the covid-19 pandemic in early childhood
}

\author{
M. Syukri Azwar Lubis' ${ }^{1}$, Hotni Sari Harahap ${ }^{2}$, Armanila ${ }^{3}$ \\ 1,3 Department of Islamic Early Childhood Education, Al Washliyah University, Medan, Indonesia \\ ${ }^{2}$ Department of Islamic Education Management, Al Washliyah University, Medan, Indonesia \\ ${ }^{*}$ corresponding author
}

First received:

24 November 2021

\section{Revised:}

27 December 2021
Final Accepted:

29 December 2021

\begin{abstract}
The COVID-19 pandemic has caused the face-to-face learning system to switch to learning from home. This transition makes parents have to adapt to these new circumstances. This study aims to determine the psychological problems of learning from home during COVID-19 in early childhood. This qualitative research with a case study approach involves parents of children aged 5-6 years, schools, and the community in Paya Geli Village, Sunggal District, Deli Serdang Regency, North Sumatra Province. Data were obtained through interviews, observation, and documentation techniques. Data analysis uses the Miles and Huberman model, including data reduction, display, and verification. The results of this study found several problems, namely: 1) Parents became stressed so that violence occurred in teaching. 2) Children become passive, uncreative, unproductive due to stress. 3) gadgets have become a place for children to escape to avoid stress. Thus, it is hoped that parents will be wiser in teaching their children at home to minimize the occurrence of psychological problems learning from home.
\end{abstract}

Keywords: psychological problems, learning from home, early childhood

${ }^{3}$ Corresponding Author:

Department of Islamic Early Childhood Education,

Al Washliyah University, Medan, Indonesia

Email: armanila88@gmail.com 


\section{INTRODUCTION}

In general, the COVID-19 pandemic has significantly impacted traditional learning, emphasizing the interaction process between teachers in the classroom and distance learning (online). This forces education stakeholders to change teaching methods by using a face-toface learning system to 'learn from home.' Many other countries have implemented learning from home (Schleicher, 2020); until the end of March 2020, around 1.6 billion children have dropped out of school in 161 countries (Dayal \& Tiko, 2020).

Kindergarten teachers play a prominent role in optimizing all children's potential to actively participate in learning activities to achieve the expected educational goals (Haudi, 2021) and build children's readiness to enter school (Syarfina et al., 2018). Educators have the task of equipping their students with knowledge, good attitudes (morals), and training them to be skilled in specific fields (Lufri, 2020). However, this is difficult to do because of limitations in all aspects. Although this situation aligns with the vision and mission of future learning in the era of industrial revolution 4.0 and community 5.0, it cannot be separated from its advantages and advantages. In terms of advantages, of course, online learning is not limited by space and time, primarily because of the government's appeal to self-quarantine, physically and socially distance. However, today's freedom cannot be interpreted as unlimited freedom in learning (Abidah et al., 2020).

If studied empirically and in-depth, many things must be addressed if the government enforces learning from home. COVID-19 has slowly but surely changed the order of life in early childhood education in this country. All this results from the absence of other activities other than playing with their peers. In line with the results of research showing that staying at home raises its problems in children, namely the emergence of stress, sensitivity, children becoming spoiled, and changes in behavior, it appears when they stay at home too long (Tabi'in, 2020). Learning from home also has positive impacts. The positive impact is to motivate students to be more severe in dealing with education. Currently, we no longer see children reading books (reading in simple contexts according to the age of 5-6 years; most of them are currently more likely to use Android or gadgets.

Learning from home will lead children to become a generation that is creative and aggressive in viewing education so that there is a collaboration between teachers and parents. Parents who were previously uncomfortable with technology are now increasingly permissive to technology. Father and mother then become teachers for their children and restore their function as the first school. Then, they found many obstacles that arise for parents. Many of them do not have enough time to accompany their children to study because they have to work. It is challenging to cultivate children's interest in learning, and children's mood is constantly changing (Haudi, 2021). Research conducted by Suciati \& Syafiq (2021) regarding parents' struggles of early childhood students during the Covid-19 pandemic showed that $80 \%$ of the 136 respondents stated that they had difficulty helping their children learn online learning. It is due to the difficulty of dividing time and priorities to 
guide children learning where parents are still very dependent on the experience and direction of the teacher when accompanying children to learn.

Children in Kindergarten experience several problems when staying at home: stress, increased sensitivity, temper tantrums, spoiled / not independent, and behavioral disorders. The obstacles for parents in accompanying children to study at home during the Covid-19 pandemic were the lack of understanding of the material by parents, the difficulty of parents in cultivating children's interest in learning, not having enough time to accompany children because they have to work, parents are impatient in accompanying children while studying at home, parents' difficulties in operating gadgets, and obstacles related to the internet service coverage (Wardhani, 2018).

Previous research by (Tabi'in, 2020) emphasizes the psychological problems in children aged 4-6 years. While the researcher will examine more specific children's psychological problems, with an age range of 5-6 years. In addition, research by (Wardhani, 2018) emphasizes the constraints faced by parents in assisting children to study at home, this type of research is a case study by conducting interviews with 12 parents with children attending kindergarten. Furthermore, the obstacles faced by parents in assisting learning at home are not explicitly listed in the title to be studied. However, this researcher aims to discover the psychological problems of learning from home during COVID-19 in children aged 5-6 years.

\section{METHOD}

The type of research used is qualitative research, with a case study approach. Researchers explore real-life, various limited systems (various cases) through detailed and indepth data collection and various sources of information. The characteristics in this case study are identifying cases bound by time and place using informant sources, parents of children aged 5-6 years.

This study aims to discover the psychological problems of learning from home during covid-19 in children aged 5-6 years in Paya Geli Village, Sunggal District, Deli Serdang Regency, North Sumatra Province. Using purposive sampling, the samples in this study were parents who have early childhood children with an age range of 5-6 years and who experienced psychological problems studying from home during the COVID-19 pandemic, schools, and communities.

Data collection techniques used are observation, interviews, and documentation. Researchers made observations to discover the psychological problems of learning from home during the covid-19 pandemic to parents and early childhood. Because this study involved the education system, observations were also made in schools by exploring the learning system and patterns of interaction between parents and teachers. Furthermore, the researcher also conducted interviews regarding the outline of the problem being studied. Finally, the researchers collected documents about activities carried out by parents and children at home and schools with their learning systems during the COVID-19 pandemic. 
Furthermore, the data collected was first validated for triangulation by checking several sources. The researcher uses the Miles and Huberman model in data analysis, including data reduction, data display, and data verification (Jarvie, 2012). Data reduction was carried out during the research process from beginning to end, which included focusing, abstracting, and transforming rough data from the field, which was part of the research analysis. Then display the data by understanding what is happening and planning further work based on what has been understood. The last is drawing conclusions based on data reduction and data presentation that has been done.

\section{RESULT AND DISCUSSION}

Based on the findings of the data obtained from interviews, observations, and documentation, several psychological problems of learning from home during covid-19 in children aged 5-6 years, namely:

1. Parents become stressed, so that violence often occurs in teaching at home.

Stress, according to psychologists, is a disorder of the body and mind caused by the changes and demands of life (Mardianto, 2018). Other psychologists state that stress is the emergence of physiological and psychological reactions if a person perceives an imbalance between the level of demands imposed on him and his ability to meet these demands. Research results from Winarti (2021) show that Covid-19 impacts the psychology of parents and children, such as stress so that children become victims of verbal violence and lose their enthusiasm for learning, which impacts developmental achievement.

Based on the results of interviewing one of the residents of Paya Geli Village, a mother who has a double role; a housewife and a working woman, she stated that:

"Saya mengalami kesulitan dalam melaksanakan atau menggantikan tugas guru bagi anak saya di rumah, baik di dalam pembentukan karakter, kepribadian, serta pendidikan atau pengajaran. Hal ini disebabkan karena banyaknya tugas atau pekerjaan saya di rumah dan ditambah dengan pekerjaan di luar rumah. Sehingga berdampak pada stres dan akhirnya mempengaruhi perilaku saya kepada anak sebagai pelampiasan."

(I have difficulty in carrying out or replacing the duties of a teacher for my child at home, both in the formation of character, personality, as well as education or teaching. It is because of many tasks or work I do at home and work outside the home. So, it has an impact on stress and ultimately affects my behavior towards children as an outlet).

She further stated that:

"Tidak jarang, pertengkaran pun sering terjadi antara saya dengan anak, karena saya mengalami kesulitan dalam mengatur tindakan anak. Saya merasa mereka kurang mendengarkan apa yang saya sampaikan, seperti disiplin waktu dalam segala kegiatan. Hal ini disebabkan karena ikatan yang lemah dan saya menyadari bahwa saya tidak selalu ada saat 
anak-anak membutuhkan bantuan dalam belajar serta tidak selalu dapat menemani mereka saat menghadapi kesulitan disebabkan rutinitas yang padat."

(Not infrequently, fights often occur between my child and me because I have difficulty in regulating the child's actions. I feel they do not listen to what I say, such as discipline in all activities. This is due to a weak of bonding, and I realized that I was not always beside them when the children needed help in learning and could not always accompany them when they faced difficulties due to the hectic routine).

Based on the opinion of the informants, it appears that the role of parents in educating their children is crucial. Nowadays, parents must also replace the role of teachers in schools. However, the phenomenon is that parents have difficulty carrying out education and teaching at home.

Many mothers have to prepare for all household needs, including economic needs. They are also required to play their role as teachers who educate and shape children's character, personality, and attitudes while at home. It shows that parents fulfill the facilities needed by children and provide vocal support. Parents should motivate children by providing support in various aspects such as inviting them to learn without scolding, giving children a sense of security and comfort, establishing harmonious relationships with children, being willing to help if children encounter difficulties, and being a model that children can imitate (Adevita \& Widodo, 2021).

Research shows that women who work outside the home stress levels are much higher than for men (Syafrizaldi, 2020). The problems experienced by parents during learning activities from home affected by the spread of covid-19 are triggered by several things; (1) children cannot be directed and seem wild for a year; they do not study face-to-face, (2) demand additional costs and basic costs during online learning such as internet packages and gadget, (3) increasingly complex economic problems such as high basic food prices and reduced income. Such are the problems that occur to parents during the pandemic so that it has an impact on caring for their children at home, which eventually leads to domestic violence. However, all the problems that arise are not used as reasons and main ingredients for doing these less than commendable things.

The effort that can become a solution to reducing stress is to draw closer to God so that all problems that arise will be unraveled and find a way out. There is nothing to worry about if we leave all our problems to God because He will not test His servant beyond the limits of His servant's ability. During this pandemic, the stress that occurs for parents is that many parents are not ready or not ready to face this period.

2. Children become passive, uncreative, unproductive; there is the accumulation of information and stress 
The sudden pandemic created new policies aiming to break the chain of virus spread. Children are also required to maintain health protocols, starting from washing hands, wearing masks, and keeping a distance. In addition, the policy also entered the area of education, changing the mechanism of the pre-school world, which has initially been face-toface to online learning. This significant change raises enormous questions for parents, and most parents end up confused about what and how.

In early childhood, learning will be less effective if it occurs online. In the learning process, a student should interact with the outside world so that communication occurs, giving birth to motivation (Lubis, 2019). Children learn it related to changes in a person's behavior in certain situations caused by repeated experiences, responses, traits, maturity, or momentary circumstances (Robert M.Gagne, 1997). Therefore, learning is better-conducted face-to-face. Another thing that triggers problems during learning from home is the accumulation of children's tasks. Several parents of the researchers interviewed said that their children became stressed due to the many tasks that piled up, which they then had difficulty controlling how to do.

3. Android becomes a place of escape for children (under the pretext of avoiding stress) Android is an object that is currently trending and loved by many people, ranging from teenagers, parents, not to mention early childhood who are at the pre-school stage. Android is like two different coins; on the one hand, it has a positive impact on its users, but on the other hand, it has a negative impact. There are many cases regarding the increasing level of addiction in early childhood to gadgets which causes children to stay in front of gadgets for long; children get angry quickly when reprimanded to stop, eat or sleep; children are far from a healthy lifestyle; children will be hampered by gross motor skills, socialemotional, language development skills, religion, and art or creativity. If this is the case, then parents must get their children used to walking, moving, and exercising (Rahman, 2005).

In addition, social problems also arise in the emergence of anti-social behavior and temper tantrums in children and emotional immaturity such as low independence of children. Research results show that children's emotional development can be seen from independent, responsible and comfortable activities (Amalinda et al., 2021). All of these problems stem from the inability of children to understand and use gadgets wisely. The presence of Android in the school system increasingly impairs the function of teachers as knowledge providers. Children can see the various information about the material they are studying related to the sub-themes-sub-sub-themes. Android becomes a teacher who gives them answers according to their questions until children in almost all parts of the world rely on Android.

In essence, teachers must create creative, innovative, and interactive online teaching through Android to improve the learning and teaching process (Pokhrel \& Chhetri, 2021). However, based on the previously described phenomenon among children, the negative behavior from the technology media is due to a lack of supervision, especially parents. This is 
also in line with the statement issued by American Media that the increased use of gadgets among children initially serves to learn. However, because parental supervision is low, their children are eventually misused (Okfalisa et al., 2020).

The author offers suggestions to the community in Paya Geli Village to provide good motivation to parents, especially to children, namely children aged 5-6 years who are affected by learning from home (Learn From Home). Both intrinsic motivation and extrinsic motivation. The author does not discuss intrinsic motivation because intrinsic motivation is the motivation that exists in a person to achieve the goals he wants to achieve, but rather extrinsic motivation. This motivation comes from outside the students themselves.

First: Ego Involvement. It is an effort to raise awareness in children to know how important an education is and all that is attached to it (Gagne, 1996). Ego involvement also provides an understanding to students of how arduous the journey of life is. Hence, it takes an attitude of endurance and hard work to increase motivation to learn.

Raising children's awareness of the importance of learning must be done continuously. This motivation works as a driving force and energy contained in a person and then causes the person to want to pursue the target to be achieved. Raising children's enthusiasm for learning from home is certainly not an easy thing, although the encouragement and motivation of parents are very decisive in achieving the goals to be achieved.

Second: Appreciation. Praise is a form of social interaction to express one's acknowledgment and admiration which is shown in verbal and non-verbal forms. Verbal praise consists of a positive evaluation of the attributes or actions of others. As a form of social manipulation, praise becomes a form of reward and behavior reinforcement.

Giving praise to children, especially when learning from home, is very useful to arouse children's enthusiasm for learning. When parents praise their children's work and efforts in learning, at the same time, their enthusiasm for learning will rise. Praise born from parents will give children confidence in facing success because with the rise of their selfconfidence, no matter how hard things are, it will be easy for children to go through it.

Third: Be a friend, not a bouncer. Every human being needs a friend in his life, including children. The results of a study also state that when the role of parents is as a friend, children will be more responsive, especially for positive things built by their parents (Laila, 2011). (Laila, 2011).

However, parents said that it was not easy being a teacher. Moreover, for mothers, on the one hand, being a housewife but on the other hand, being a companion teacher for their children at home. It is conceivable that if it turns out that the mother has never received an education at school or has a higher parental educational background, it will certainly be a problem for parents. Usually, parents will become angry, and in some cases, parents do not 
hesitate to hit or say they should not to their children. Therefore, creating good communication with children is very important. The early childhood learning process is inseparable from the interaction between children and parents to achieve developmental tasks (Akbar, 2020). Good parents can set an example for their children, and wise parents can learn many things from their children.

\section{CONCLUSION}

Based on the study results, some psychological problems of learning from home during covid-19 for children aged 5-6 years are as follows; 1 ) Parents become stressed, and even violence occurs in teaching at home. 2) Children become passive, uncreative, unproductive; there is the accumulation of information and stress. Furthermore, 3) Android becomes a place of escape for children (under the pretext of avoiding stress). Thus, hopefully, parents will be wiser in educating and playing their children's role as parents and teachers at home. Continue to be good parents, parents, and friends for children and parents who always pray for the best to God to minimize the possibility of these psychological problems

\section{REFERENCE}

Adevita, M., \& Widodo. (2021). Peran Orang Tua Pada Motivasi Belajar Anak Dalam Pembelajaran Daring Di Masa Pandemi Covid-19. Jurnal Pendidikan Luar Sekolah, 5(1), 64-77.

Akbar Elliyil. (2020). Metode Belajar Anak Usia Dini. Prenada MediaGroup.

Amalinda, K. N., Virantika, M., \& Arisca, M. (2021). JURNAL INDRIA Jurnal Ilmiah Pendidikan PraSekolah dan Sekolah Awal The Impact Of Lockdown On Early Childhood Emotional Development Khassani Nur Amalinda, Melinda Virantika, Maiya Arisca. The Impact Of. 7255(1), 40-47.

Arikunto, S. (2010). Prosedur Penelitian. Rineka Cipta.

Armanila, K. (2018). Bermain dan Permainan Anak Usia Dini. Perdana Publishing.

Baharuddin, \& Wahyuni, E. N. (2015). Teori Belajar dan Pembelajaran. Yogyakarta: Ar Ruzz Medan.

Dayal, H. C., \& Tiko, L. (2020). When are we going to have the real school? A case study of early childhood education and care teachers' experiences surrounding education during the COVID-19 pandemic. Australasian Journal of Early Childhood, 45(4), 336-347. https://doi.org/10.1177/1836939120966085

D. Mutakinati, L. (2020). The Impact of Covid-19 to Indonesian Education and Its Relation to the Philosophy of "Merdeka Belajar." Studies in Philosophy of Science and Education, 1(1), 38-49. https://doi.org/10.46627/sipose.v1i1

Hasan, M. (2010). Pendidikan Anak Usia Dini. Diva Press. 
Haudi. (2021). Strategi Pembelajaran. Insan Cendekia Mandiri.

Hilgenheger, N. (2000). Johann Friedrich herbart (1776-1841). UNESCO: International Bureau of Education, XXIII(3).

John W. Santrock. (2007). Perkembangan Anak. Penerbit Erlangga.

Kemendikbud. (2014). Peraturan Menteri Pendidikan dan Kebudayaan Republik Indonesia Nomor 146 Tahun 2014 Tentang Kurikukum 2013 Pendidikan Anak Usia Dini. Kemendikbud Pendidikan Anak Usis Dini, 2025(1679), 1-68.

khadijah. (2016). Belajar dan Pembelajaran (Revisi). Perdana Mulya Sarana.

Lubis, A. M. (2019). Psikologi Belajar: Sebagai Sebuah Pendekatan. Socfindo Media Persada.

Lufri, dkk. (2020). Metodologi Pembelajaran: Strategi, Pendekatan, Model, Metode Pembelajaran. CV IRDH.

Mike, D. B. dan H. (2016). Quantum Learning: Membiasakan Belajar nyaman dan Menyenangkan (Penerjemah Alawiyah Abdurrahman (ed.); 2nd ed.). Kaifa Learning.

Monks, F.J, Knoers, S. R. H. (2002). Psikologi Perkembangan: Pengantar dalam Berbagai Bagiannya (Cet-14). Gadjah Mada University Press.

Nana Syaodih, S. (2010). Metode Penelitian Pendidikan. PT. Remaja Rosydakarya.

Okfalisa, O., Budianita, E., Irfan, M., Rusnedy, H., \& Saktioto, S. (2020). The Classification of Children Gadget Addiction: The Employment of Learning Vector Quantization 3. IT Journal Research and Development, 5(2), 158-170. https://doi.org/10.25299/itjrd.2021.vol5(2).5681

Pokhrel, S., \& Chhetri, R. (2021). A Literature Review on Impact of COVID-19 Pandemic on Teaching and Learning. Higher Education for the Future, 8(1), 133-141. https://doi.org/10.1177/2347631120983481

Putra Nusa, D. N. (2013). Penelitian Kualitatif PAUD (3rd ed.). PT. Raja Grafindo Persada.

Rahman, J. A. (2005). Tahapan Mendidik Anak,: Teladan Rasulullah, Terj. Bahrun Abubakar Ihsan Zubaidi.

Robert M.Gagne. (1997). The Condition of Learning (Second ed.). Holt: Rienhart and Winston, Inc.

Schleicher, A. (2020). The impact of COVID-19 on education: Insights from education at a glance 2020. OECD Journal: Economic Studies, 1-31.

Suciati, P., \& Syafiq, A. (2021). School From Home (SFH): Perjuangan Para Orang Tua Siswa Usia Dini Di Masa Pandemi Covid-19. Jurnal Sosial Humaniora Terapan, 3(2), 7-16.

Syafrizaldi, S. (2020). Employee work stress based on gender differences during the COVID19 Pandemic. INSPIRA: Indonesian Journal of Psychological Research, 1(2), 30-37. https://doi.org/10.32505/inspira.v1i2.2835 
Tabi'in, A. (2020). Problematika Stay At Home Pada Anak Usia Dini Di Tengah Pandemi Covid 19. Jurnal Golden Age, 4(01), 190-200. https://doi.org/10.29408/jga.v4i01.2244

Winarti, S., Taib, B., Alhadad, B., \& Achmad, F. (2021). Analisis Dampak Covid-19 Dalam Proses Pembelajaran Daring Pada Kelas B4 Di Paud Telkom Ternate. Jurnal Ilmiah Cahaya Paud, 3(1), 150-159. https://doi.org/10.33387/cp.v3i1.3140

Wiyani, N. A. (2017). Manajemen PAUD Berdaya Saing. Gava Media. 